\title{
ELECTRON-IMPACT DOUBLE IONIZATION OF TUNGSTEN ATOMS AND IONS AT LOW IONIZATION STAGES
}

\author{
V. Jonauskas a , S. Kučas ${ }^{\text {a }}$, and R. Karazija ${ }^{\text {a,b }}$ \\ a Institute of Theoretical Physics and Astronomy of Vilnius University, A. Goštauto 12, LT-01108, Vilnius, Lithuania \\ E-mail: jvaldas@itpa.lt, karazija@itpa.lt \\ ${ }^{\mathrm{b}}$ Vilnius Pedagogical University, Studentu 39, LT-08106, Vilnius, Lithuania
}

Received 20 October 2009; revised 11 December 2009; accepted 18 December 2009

\begin{abstract}
The double ionization of neutral tungsten atoms and $\mathrm{W}^{2+}, \mathrm{W}^{4+}$, and $\mathrm{W}^{6+}$ ions by electron impact is investigated. The calculations are performed taking into account the Auger decay of single ionization states with inner vacancies in the $4 \mathrm{~d}, 4 \mathrm{f}, 5 \mathrm{~s}$, $5 \mathrm{p}$, and $5 \mathrm{~d}$ shells as well as the direct double ionization using sudden perturbation model. The direct single ionization crosssection is obtained in relativistic distorted wave or binary-encounter-dipole approximations; the contribution from the indirect ionization by excitation-autoionization process is included too. It is shown that both processes - Auger decay of inner vacancy states and direct double ionization - play an important role in the double ionization process. The calculated cross-sections are compared with the experimental data.
\end{abstract}

Keywords: tungsten, electron-impact double ionization, Auger transitions, sudden perturbation

PACS: 34.50.Fa, 52.20.Fs, 31.15.A-

\section{Introduction}

Due to a very low sputtering rate of tungsten it is used as the first wall material in tokamaks, especially in the divertor region. However, some its ions migrate to the central region of discharge and may be a reason of large radiation losses. Thus the modelling of the production of tungsten ions is an urgent task. Much theoretical and experimental work has been done in investigating the electron impact single-ionization of tungsten ions [1-6]. In the case of neutral atoms the experimental data are absent, only the calculation results are available $[2,6]$. The double ionization of tungsten ions at low ionization stages was measured and described by the semi-empirical formula [7]; no ab initio calculations till now have been made.

There are two possible processes giving contribution to the multiple ionization: Auger transitions following the deexcitation of the initial state with a vacancy in an inner shell as well as the direct multiple ionization. The importance of the Auger and radiative cascades in plasma modelling was stressed in $[8,9]$. It was pointed out [8] that the essential part of the level population in some highly charged ions originated from inner shell ionization; this process was not yet considered in the database ADAS. Thus it is up-and-coming to investi- gate the role of the Auger decay of the states with a vacancy and the direct double ionization in the production of tungsten ions during their interactions with electrons.

The aim of this work is the investigation of double ionization of tungsten atoms and ions at the low ionization stages, namely, for $\mathrm{W}, \mathrm{W}^{2+}$, and $\mathrm{W}^{4+}$ in the region of electron energies from the process threshold up to $1000 \mathrm{eV}$ and for $\mathrm{W}^{6+}$ up to $5000 \mathrm{eV}$.

\section{Results of calculation and their discussion}

We will consider the double ionization of ions as a two-step process: the initial single ionization by electron impact and the following autoionization or additional ionization due to a sudden perturbation of electronic shells.

Calculations of energy level spectra, cross-sections of single ionization and excitation by electron impact as well as of Auger transitions rates have been performed using the Flexible Atomic Code [10]. In this complex of programs the relativistic Dirac-Fock-Slater wave functions are used. The mixing of all relativistic configurations corresponding to the same nonrelativistic configuration is taken into account. The results of calculations with this code of single and double ionization thresholds for the considered ions correspond with the 
average accuracy of $0.13 \mathrm{eV}$ to their values obtained by multiconfiguration Dirac-Fock code [7], but differ by 1-2 eV from experimental and empirical values compiled in [11].

At first we will consider the single ionization of ions, because in the following its cross-section will be used for the calculation of double ionization of ions. For $\mathrm{W}^{4+}$ and $\mathrm{W}^{6+}$ the direct single electron impact ionization is calculated in the distorted wave approximation (DWA). For near neutrals the DWA tends to overestimate the experiment [5] and more accurate results are given by the binary-encounter approximation [6]. Thus in the case of $\mathrm{W}$ and $\mathrm{W}^{2+}$ the binary-encounter-dipole (BED) model [12] is used. Also the indirect ionization process of excitation-autoionization is included; it gives for such tungsten ions a significant contribution to the single ionization cross-section $[4,5,7]$. It is supposed that $\mathrm{W}$ and $\mathrm{W}^{2+}, \mathrm{W}^{4+}$ ions are in the initial ground state. In the case of $\mathrm{W}^{6+}$ ion we accept the assumption made in $[4,7]$ that most of the ions are ionized from the metastable states of the excited $5 p^{6} 4 f^{13} 5 d$ configuration. The lowest level of this configuration is ${ }^{3} \mathrm{D}_{2}$, however, it can be deexcited to $5 \mathrm{p}^{6} 4 \mathrm{f}^{14}$ configuration by the electric quadrupole transitions. Thus we consider the ionization from the second long-living level ${ }^{3} \mathrm{D}_{5}$. At the energies of electron beam up to about thousand electronvolts used in the experiment [7] for $\mathrm{W}^{2+}$, $\mathrm{W}^{4+}$ ions, the single ionization of $4 \mathrm{~d}, 4 \mathrm{f}, 5 \mathrm{~s}, 5 \mathrm{p}$, and $5 \mathrm{~d}$ shells is necessary to take into account [5]. In the case of $\mathrm{W}^{6+}$ the cross-sections of single and double ionization were measured up to $5000 \mathrm{eV}$; then the ionization of deeper shells becomes possible, however, their contribution to both cross-sections is small.

In $\mathrm{W}$ and $\mathrm{W}^{2+}$ the largest contribution to the direct single electron impact ionization cross-section is given by the ionization of $5 \mathrm{~d}$ shell. In $\mathrm{W}$ the ionization of 6s shell also plays an important role (Figs. 1, 2). For $\mathrm{W}^{4+}$ and $\mathrm{W}^{6+}$ the role of $4 \mathrm{f}$ ionization increases due to a contraction of $4 \mathrm{f}$ orbital and decrease of $5 \mathrm{~d}$ electron number in this shell (Figs. 3, 4).

In calculations of the indirect single ionization process the largest contributions are given by the following excitations: $6 \mathrm{~s}-6 \mathrm{p}, 5 \mathrm{~d}-6 \mathrm{p}$, and $5 \mathrm{p}-5 \mathrm{~d}$ for $\mathrm{W} ; 5 \mathrm{~d}-$ $6 \mathrm{p}, 5 \mathrm{p}-5 \mathrm{~d}, 6 \mathrm{~s}$ for $\mathrm{W}^{2+} ; 5 \mathrm{p}-5 \mathrm{~d}$ and $5 \mathrm{~d}-6 \mathrm{p}, 5 \mathrm{f}$ for $\mathrm{W}^{4+}$, and $5 \mathrm{~d}-5 \mathrm{f}, 5 \mathrm{p}-5 \mathrm{~d}, 4 \mathrm{f}-5 \mathrm{~d}$ for $\mathrm{W}^{6+}$. The excitationionization part of single ionization cross-section augments its value given by the direct ionization. The contribution of two-step process to the cross-section peak value increases with the charge of ion: $14.7 \%$ for $\mathrm{W}$, $32.1 \%$ for $\mathrm{W}^{2+}, 58.8 \%$ for $\mathrm{W}^{4+}$, and $59.5 \%$ for $\mathrm{W}^{6+}$.

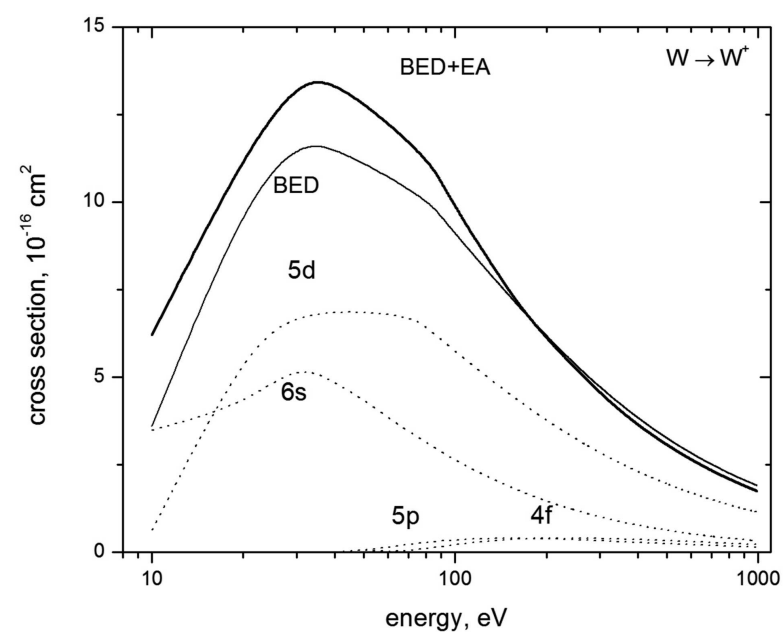

Fig. 1. Electron-impact single ionization cross-section of neutral W atoms. Results of calculation: dotted curves, contributions from separate shells to the direct ionization; full curve, total direct ionization; solid line, single ionization including direct ionization and excitation-autoionization. Direct ionization is calculated in BED approximation.

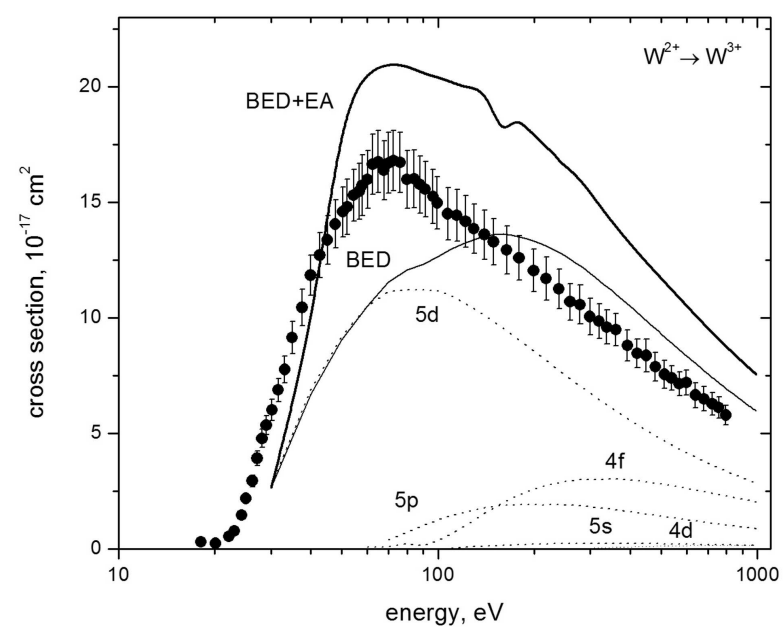

Fig. 2. Electron-impact single ionization cross-section of $\mathrm{W}^{2+}$ ions. Experiment [3], points with error bars. Results of calculation: dotted curves, contributions from separate shells to the direct ionization; full curve, total direct ionization; solid line, single ionization including direct ionization and excitation-autoionization. Direct ionization is calculated in BED approximation.

The obtained total single ionization cross-section $\sigma^{+}(\varepsilon)$ for $\mathrm{W}^{4+}$ and $\mathrm{W}^{6+}$ corresponds well to the experimental data. For $\mathrm{W}^{2+}$ the cross-section $\sigma^{+}(\varepsilon)$ is obtained about 1.2 times higher at its peak than the experimental value [7] (Fig. 2).

According to the diagram of energy level spectra (Fig. 5) the additional single and even double ionization of tungsten ions is possible by Auger transitions from the states with the inner vacancy in the $4 l^{-1}$ and $5 l^{-1}$ shells. Our results of the double ionization limits for $\mathrm{W}^{2+}(61.3 \mathrm{eV})$ and $\mathrm{W}^{4+}(114.0 \mathrm{eV})$ practically 


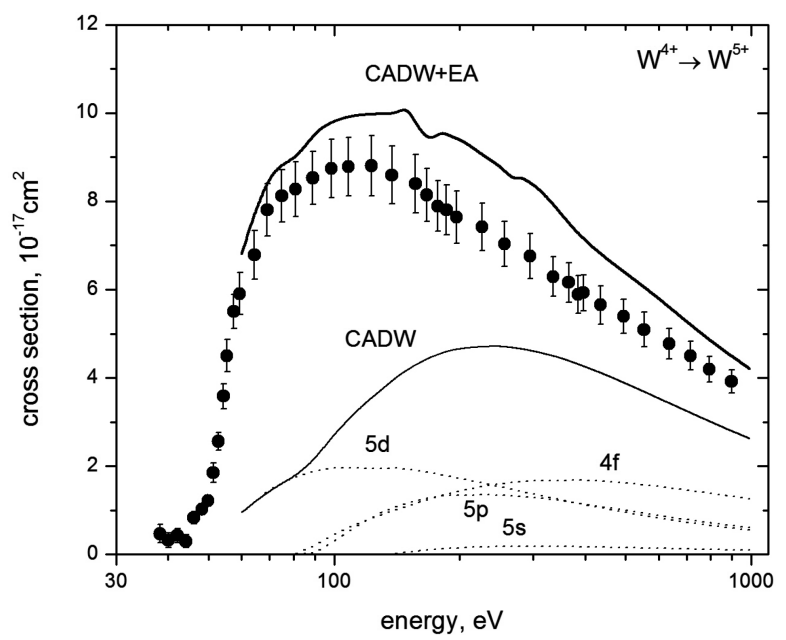

Fig. 3. Electron-impact single ionization cross-section of $\mathrm{W}^{4+}$ ions. Experiment [3], points with error bars. Results of calculation in DWA approximation: dotted curves, contributions from separate shells to the direct ionization; full curve, total direct ionization; solid line, single ionization including direct ionization and excitation-autoionization.

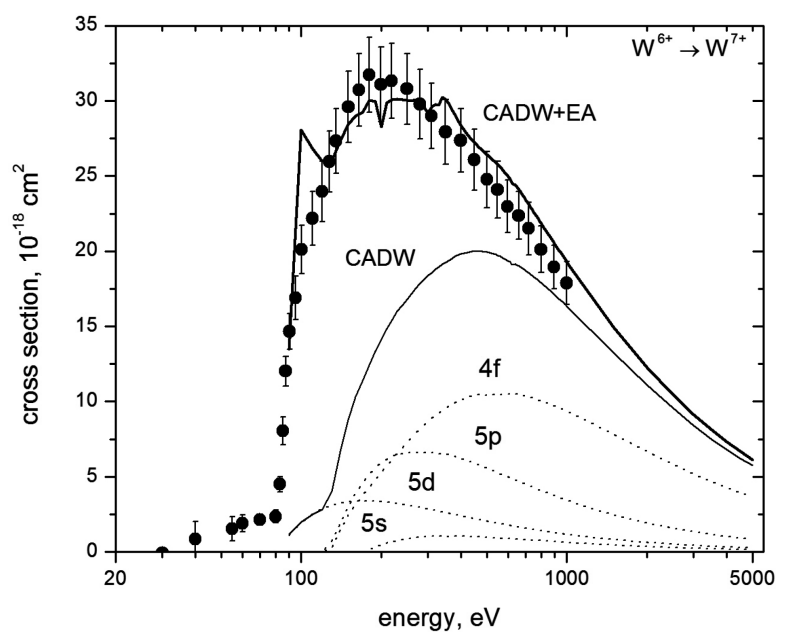

Fig. 4. Electron-impact single ionization cross-section of $\mathrm{W}^{6+}$ ions. Experiment [3], points with error bars. Results of calculation in DWA approximation: dotted curves, contributions from separate shells to the direct ionization; full curve, total direct ionization; solid line, single ionization including direct ionization and excitation-autoionization. It is supposed that most of the ions are ionized from the metastable states of the excited $5 p^{6} 4 f^{13} 5 d$ configuration.

coincide with the values $61.4 \mathrm{eV}$ and $114 \mathrm{eV}$ calculated by multiconfiguration Dirac-Fock method [7].

Usually the method of global characteristics of spectra [13] is used for the calculation of ion yields produced by Auger cascade between complex configurations. However, the energy spectra of initial and final configurations of considered tungsten ions with vacancies in outermost shells are not distant energetically or they even overlap. Thus it is necessary to perform more

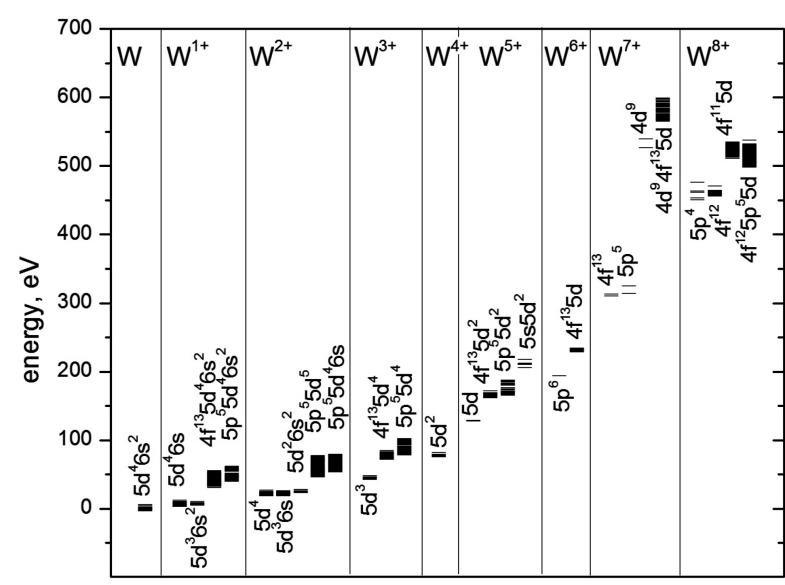

Fig. 5. Energy level spectra of ions involved in Auger transitions after the ionization of initial ion. The positions of levels are given with respect to the ground level of neutral atom $\mathrm{W}$.

complex level-by-level calculations. The wave functions of Auger electrons as well as of bound states have been calculated in the central potential of autoionizing ion (before autoionization) using its lowest lying relativistic configuration. Acording to the obtained results the most probable Auger transitions end in the configurations of the next ionization stage.

The probablity of double ionization by Auger transitions in the tungsten atom and first ions mainly depends on the energetic position of $4 \mathrm{f}^{-1}$ and $5 \mathrm{p}^{-1}$ vacancies' states with respect to the autoionization limit. $\mathrm{In}^{+}$ the transitions from all such states to the states of $\mathrm{W}^{2+}$ are energetically permitted. In $\mathrm{W}^{3+}$ only the Auger decay from some levels of $5 \mathrm{p}^{5} 5 \mathrm{~d}^{4}$ configuration is possible in the single configuration approximation, thus the $\mathrm{W}^{4+}$ ions are mainly obtained by the decay of $5 \mathrm{~s}^{-1}$ and $4 \mathrm{~d}^{-1}$ vacancy states. However, after taking into accout a rather strong interaction between $4 \mathrm{f}^{-1}$ and $5 \mathrm{p}^{-1}$ configurations one highly populated level of $5 \mathrm{p}^{5} 5 \mathrm{~d}^{4}$ configuration is shifted through autoionization threshold, leading to the essential increase of Auger transition contribution to the double ionization cross-section of $\mathrm{W}^{2+}$ ion. In $\mathrm{W}^{5+}$ already the Auger transitions from all levels of $4 \mathrm{f}^{-1} 5 \mathrm{~d}^{2}$ as well as $5 \mathrm{p}^{-1} 5 \mathrm{~d}^{2}$ configurations are forbidden in single configuration approximation. By taking into account the interaction of these configurations as well as of $\mathrm{W}^{6+} 5 \mathrm{p}^{6}$ with 5-7 neighbouring configurations, the indicated level is shifted to the autoionization threshold, but remains $3 \mathrm{eV}$ below it. However, it is probable that including more correlation effects this level can give a contribution to the double ionization cross-section. In $\mathrm{W}^{7+}$ the levels of $4 \mathrm{f}^{-1}$ and $5 \mathrm{p}^{-1}$ configurations are lying essentialy below the autoionization threshold and the main contribution to the production of 
$\mathrm{W}^{8+}$ ions is given by the Auger decay of $4 \mathrm{~d}^{-1}$ vacancy states.

The additional electron can also be removed from an ion or excited as a result of its strong perturbation at the creation of initial vacancy. We have approximately estimated the contribution of these shake-off and shake-up processes to the double ionization in the average configuration approximation. The probability for all electrons to remain in $n l^{N}$ shell at the production of $n_{0} l_{0}^{-1}$ vacancy is expressed as follows:

$$
A_{0}\left(n_{0} l_{0}^{-1} n l^{N}\right)=\left\langle n l_{K} \mid n l_{K_{1}}\right\rangle^{2 N},
$$

where the subscript indicates the configuration, the wave functions of which are used for the calculations of overlap integral: $K$ is the initial configuration without vacancies and $K_{1} \equiv K n_{0} l_{0}^{-1}$. Thus the probability that one electron will be removed from $n l^{N}$ shell and all its other electrons will remain unperturbed at the single ionization of $n_{0} l_{0}^{N_{0}}$ shell is expressed as

$$
\begin{aligned}
A\left(n_{0} l_{0}^{-1} n l^{-1}\right)= & N\left[1-\left\langle n l_{K} \mid n l_{K_{1}}\right\rangle^{2}\right] \\
& \times\left\langle n l_{K} \mid n l_{K_{1}}\right\rangle^{2(N-1)} .
\end{aligned}
$$

Here the term excluding the excitations into the occupied states is omitted, because it is practically negligible at the production of vacancies in the outer shells. Probability $A\left(n_{0} l_{0}^{-1} n l^{-1}\right)$ has been calculated using quasirelativistic wave functions [14]. While most of the states with a vacancy and an excited electron autoionize into a state of the next ion, Eq. (2) gives the estimation of shake process probability to the double ionization of ion. Then the cross-section of double ionization due to shake process after electron impact ionization of $n_{0} l_{0}^{N_{0}}$ shell gets:

$$
\sigma^{++}(\varepsilon)=\sum_{n_{0} l_{0}} \sigma_{n_{0} l_{0}}^{+}(\varepsilon) \sum_{n l} A\left(n_{0} l_{0}^{-1} n l^{-1}\right),
$$

where $\varepsilon$ is the energy of incident electron. Only energetically possible shake transitions must be included. The probability $\sum_{n l} A\left(n_{0} l_{0}^{-1} n l^{-1}\right)$ obtains its largest value, exceeding $15 \%$, for $4 \mathrm{f}^{-1}$ vacancy in neutral atoms (Fig. 6). The sudden perturbation of outer shells is weaker at the production of $5 l^{-1}$ vacancies. The probability to remove an additional electron diminishes on increasing the ionization degree.

In Figs. 7-10 the results of calculation of electronimpact double ionization cross-sections for the considered ions are presented. The total cross-section of double ionization is obtained smaller than the experimental data [7]: the peak value is underestimated by $25 \%$ for

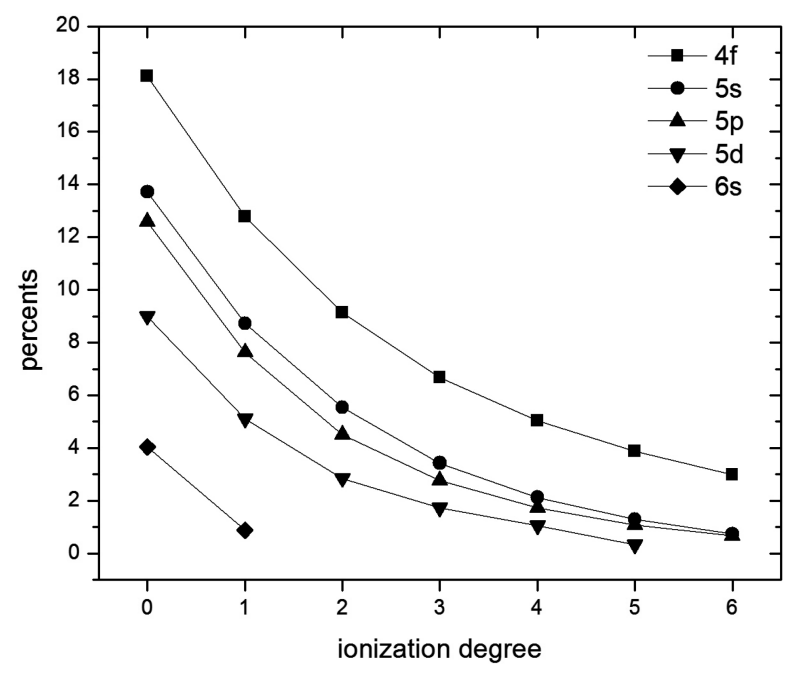

Fig. 6. The values of the probability $\sum_{n l} A\left(n_{0} l_{0}^{-1} n l^{-1}\right)$ to remove one electron from any other shell of ion at the production of $n_{0} l_{0}^{-1}$ vacancy. Results of calculation according to Eq. (2) in quasirelativistic approximation.

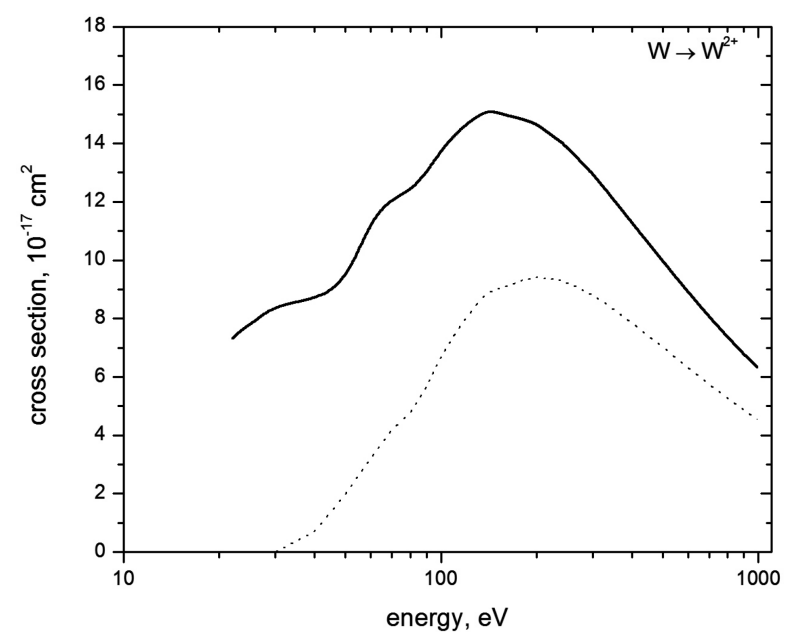

Fig. 7. Electron-impact double ionization cross-section of neutral W atoms. Results of calculation: dotted curve, single ionization following the Auger transitions; full curve, total double ionization.

$\mathrm{W}^{2+}, 58 \%$ for $\mathrm{W}^{4+}$, and $33 \%$ for $\mathrm{W}^{6+}$. The contributions from the Auger transitions and from the sudden perturbation are of the same order, though the last process plays a smaller role, especially for the higher ions. For $\mathrm{W}, \mathrm{W}^{2+}$, and $\mathrm{W}^{4+}$ the double ionization due to sudden perturbation is dominated by the initial ionization of $4 \mathrm{f}$ shell, however, at the ionization of metastable states of $\mathrm{W}^{6+}$ the influence of the production of $5 \mathrm{~d}^{-1}$ vacancy becomes also essential.

\section{Conclusions}

The large scale calculations have been performed in order to obtain the theoretical double ionization cross- 


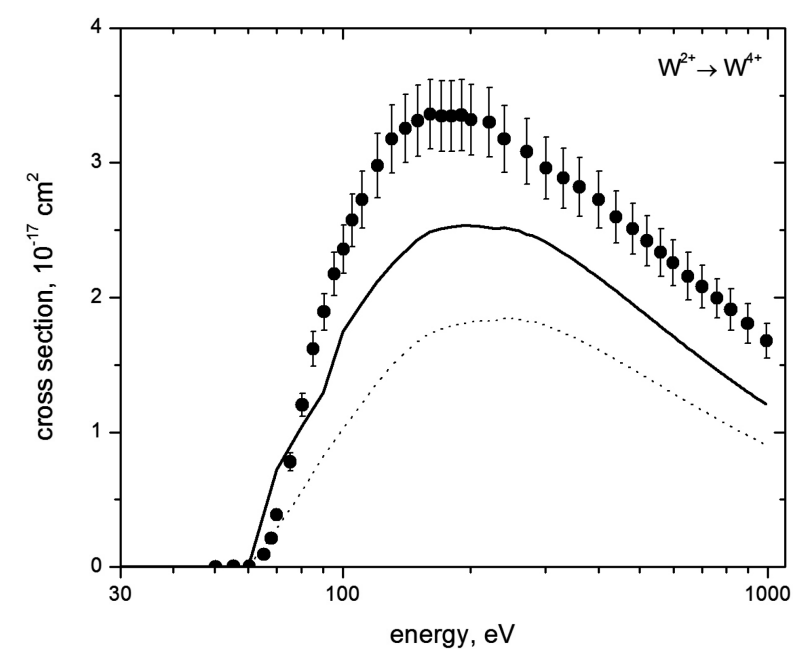

Fig. 8. Electron-impact double ionization cross-section of $\mathrm{W}^{2+}$ ions. Experiment [7], points with error bars. The meaning of other points and curves is the same as in Fig. 7.

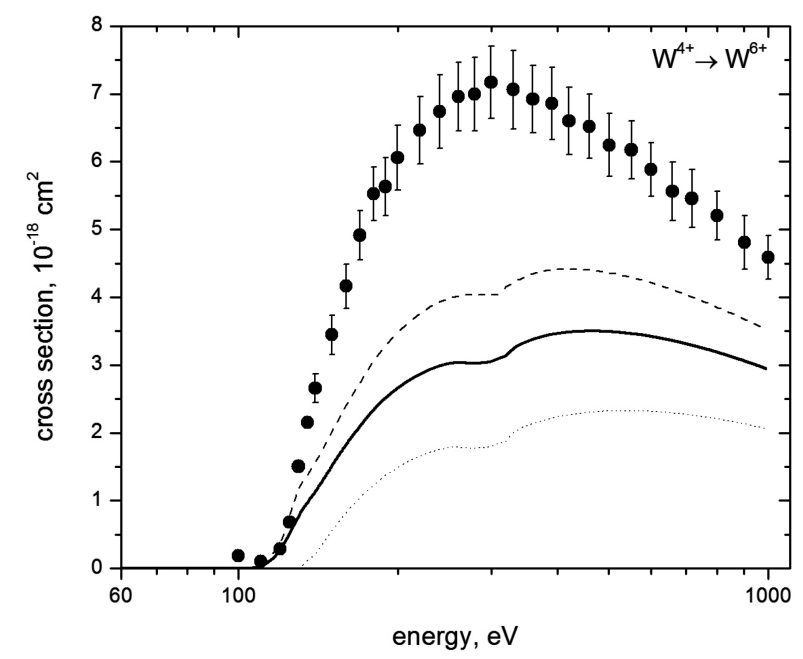

Fig. 9. Electron-impact double ionization cross-section of $\mathrm{W}^{4+}$ ions. Experiment [7], points with error bars. The meaning of other points and curves is the same as in Fig. 7. Dashed curve, the total double ionization after the energy of $5 \mathrm{p}^{6}$ level for $\mathrm{W}^{6+}$ ion is lowered by $3 \mathrm{eV}$.

sections for the tungsten atoms and for $\mathrm{W}^{2+}, \mathrm{W}^{4+}$, and $\mathrm{W}^{6+}$ ions; till now only the empirical results were known for the considered ions and data absent at all for the neutral atoms. Two possible mechanisms of double ionization by electron impact have been investigated. After the single ionization of $4 \mathrm{~d}, 4 \mathrm{f}, 5 \mathrm{~s}$, and $5 \mathrm{p}$ shells some their states can decay by Auger transitions into the states of ions with one and even two higher ionization stages. Because such transitions take place between neighbouring or overlapping configurations the detailed level-by-level calculations have been performed. The direct double ionization of ions has been considered as a two-step process: the initial single ionization by

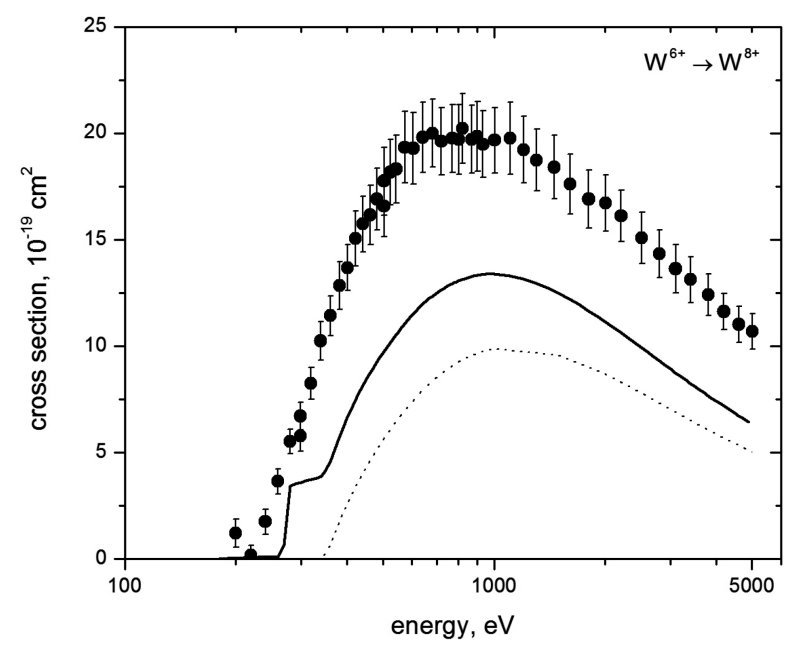

Fig. 10. Electron-impact double ionization cross-section of $\mathrm{W}^{6+}$ ions. Experiment [7], points with error bars. The meaning of other points and curves is the same as in Fig. 7.

electron impact and the additional ionization due to a sudden perturbation of electronic shells. The contributions from the Auger transitions and from the sudden perturbation to the double ionization cross-section are obtained to be of the same order, though the last process plays a smaller role, especially for the higher ions.

\section{Acknowledgements}

We gratefully acknowledge Prof. E. Salzborn for the permission to reproduce experimental data of single and double ionization cross-section for the tungsten ions. Our work was partly supported by the Joint Taiwan-Baltic Research project and the Ministry of Education and Science of Lithuania, agreement No. SUT683. The calculations were partly funded by the European Commission project RI026715 BalticGrid, and also by the Lithuanian State Science and Studies Foundation in the frame of LitGrid and GridTechno.

\section{References}

[1] R.G. Montague and M.F.A. Harrison, J. Phys. B 17, 2707 (1984).

[2] M.S. Pindzola and D.C. Griffin, Phys. Rev. A 46, 2486 (1992).

[3] M. Stenke, K. Aichele, D. Harthiramani, G. Hofmann, M. Steidl, R. Volpel, and E. Salzborn, J. Phys. B 28, 2711 (1995).

[4] M.S. Pindzola and D.C. Griffin, Phys. Rev. A 56, 1654 (1997).

[5] S.D. Loch, J.A. Ludlow, M.S. Pindzola, A.D. Whiteford, and D.C. Griffin, Phys. Rev. A 72, 052716 (2005). 
[6] D.-H. Kwon, Y.-J. Rhee, and Y.-K. Kim, Int. J. Mass Spectrom. 252, 213 (2006).

[7] M. Stenke, K. Aichele, D. Hathiramani, G. Hofmann, M. Steidl, R. Volpel, V.P. Shevelko, H. Tawara, and E. Salzborn, J. Phys. B 28, 4853 (1995).

[8] T. Pütterich et al., in: 31st Conference on Plasma Physics, London, Europhysics Conference Abstracts 28G, 4.136 (2004).

[9] S.D. Loch, M.S. Pindzola, C.P. Ballance, and D.C. Griffin, J. Phys. B 39, 85 (2006).
[10] M.F. Gu, Astrophys. J. 582, 1241 (2003).

[11] A.E. Kramida and J. Reader, At. Data Nucl. Data Tables 92, 457 (2006).

[12] Y.-K. Kim and M.E. Rudd, Phys. Rev. A 50, 3954 (1994).

[13] R. Karazija, S. Kučas, and V. Jonauskas, Lithuanian J. Phys. 44, 183 (2004).

[14] R.D. Cowan, The Theory of Atomic Structure and Spectra (University of California Press, Berkeley, CA, 1981).

\title{
DVIKARTINĖ VOLFRAMO ATOMŲ IR PIRMŲJŲ JONŲ JONIZACIJA ELEKTRONŲ SMŪGIU
}

\author{
V. Jonauskas a, S. Kučas ${ }^{\text {a }}$, R. Karazija ${ }^{\text {a,b }}$

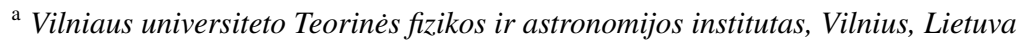 \\ ${ }^{\mathrm{b}}$ Vilniaus pedagoginis universitetas, Vilnius, Lietuva
}

\section{Santrauka}

Volframas, kaip labai atspari danga, naudojamas naujos kartos tokamako įrenginiuose, numatomas naudoti ir projektuojamame ITER tokamake. Tačiau net nedideli jo kiekiai, patekę nuo ịrenginio sieneliu i plazmą, sukelia nemažus radiacinius nuostolius, todèl yra svarbu ištirti ịvairaus kartotinumo volframo jonų susidarymo galimybes. Iki šiol, sprendžiant balanso lygtis, nebūdavo atsižvelgiama i dvikartinę volframo atomu jonizaciją, jiems sąveikaujant su plazmos elektronais. Pateikiami pirmieji tokio proceso šiam elementui skerspjūvių teorinių skaičiavimų rezultatai.

Tiesioginès vienkartinès jonizacijos skerspjūvis buvo skaičiuotas reliatyvistiniu sutrikdytųjų bangų ir dvinario susidūrimo metodais, taip pat buvo atsižvelgta i dvipakopès jonizacijos, sukuriant sužadintus lygmenis, o po to vykstant jų autojonizacijai, indèlį. Po 4d, 4f, 5s ir 5p sluoksnių vienkartinės jonizacijos galimi Auger šuoliai, kuriu metu atomo jonizacijos laipsnis padidèja vienetu ar dviem. Kadangi tokie šuoliai vyksta tarp energetiškai gretimu ar persiklojančių konfigūracijų, reikia atlikti detalius šuolių tarp lygmenų skaičiavimus; jie buvo vykdomi reliatyvistiniu konfigūracijų maišymosi artutinumu. Tiesioginė dvikartinè jonizacija buvo nagrinejjama kaip dvipakopis procesas: vienkartinè jonizacija elektronų smūgiu ir papildoma jonizacija dèl elektronų staigaus trikdžio. Auger šuolių ir staigios perturbacijos indèliai į dvigubos jonizacijos skerspiūvi gaunami panašios eilès, tačiau antrasis procesas vaidina mažesni vaidmenį, ypač didesnio jonizacijos laipsnio jonuose. Apskaičiuoti skerspjūviai kokybiškai atitinka eksperimentinius duomenis. 